\title{
ИДЕНТИЧНОСТЬ ЗАВОДСКОГО РАБОЧЕГО В ПОСТСОВЕТСКОМ КОНТЕКСТЕ: ЭТНОГРАФИЧЕСКОЕ КЕЙС-СТАДИ РАЙОНА УРАЛМАШ
}

\begin{abstract}
Статья обращена к изучению идентичности представителей рабочего класса. Исследование основано на концепции культурологического анализа классов и подходе генетического структурализма Пьера Бурдье, согласно которому классовый габитус представляет собой систему устойчивых диспозиций, порождающих социальные практики и встроенных в социальные отношения. Эмпирическим объектом исследования выступают рабочие Уралмашзавода- одного из крупнейших заводов СССР, который продолжает функционировать и сегодня. Исследование проходило на территории района Уралмаш, построенного в 1920-е гг. в городе Свердловск (ныне Екатеринбург). Полевое исследование выполнено в жанре этнографического кейс-стади. Во время сбора данных, в мае-июне 2017 г., коллектив исследователей во главе с авторами статьи стали временными жителями района Уралмаш. На примере уральского кейса показано, что современный заводчанин на постсоветском пространстве является носителем множественной и фрагментарной идентичности, в которой объединяются «советские» и «постсоветские» практики и ценности. Рабочие описывают себя в категориях «простые люди», «хороший человек», через личные качества и ценности такие, как «честность», «трудолюбие», «общительность», «достоинство», «простота», а также идентичности частной жизни, вне сферы труда (семьянин, пенсионер, садовод). Многие представители старшего поколения осознают себя как люди, «живущие в прошлом», «советские»
\end{abstract}

Елизавета Валерьевна Полухина- к.с.н., доцент, факультет социальных наук, Национальный исследовательский университет «Высшая школа экономики», Москва, Россия. Электронная почта: epolukhina@hse.ru

Александрина Владимировна Ваньке- к.с.н., докторант, департамент социологии, Манчестерский университет, Манчестер, Великобритания, научный сотрудник ГАУГН, научный сотрудник ФНИСЦ РАН, Москва, Россия. Электронная почта: a.vanke@postrgad.macnhester.ac.uk 
люди. Таким образом, для старшего поколения заводчан советское прошлое по-прежнему остается главным ресурсом и универсальной опорой, которая поддерживает их самовосприятие. Смыслообразующим ресурсом для идентичности уралмашевцев является «районный» патриотизм. Однако, как показывают данные наших наблюдений и интервью, рабочие в постсоветское время становятся все более «невидимой» группой в районе и, в силу сложившихся привычек, отказываются перенимать новые стили жизни, предлагаемые пришедшими в район новыми акторами (застройщики, культурные деятели, представители инфраструктуры развлечений). Кроме того, работник завода в постсоветском времени утрачивает классовую идентичность, характерную для советского периода. В результате рабочие воспроизводят или заново присваивают иные идентификационные типы, но сохраняют при этом память о советском прошлом и пытаются найти основания для идентичности вне сферы труда, в приватной, непубличной жизни.

Ключевые слова: индустриальный район, заводской рабочий, идентичность рабочего класса, этнографическое кейс-стади, Уралмаш

DOI: 10.17323/727-0634-2019-17-2-237-252

Проблемы классовой идентичности в целом и идентичности рабочего класса, в частности, имеют определенную традицию в социальных науках. Как пишет Майк Сэвэдж, к примеру, в Великобритании три фазы изучения данного вопроса (Savage 2005:929-930): поствоенный период 1950-х гг., когда социальные ученые сосредоточились на классовом самосознании рабочих, далее период 1970-х-1990-х гг., отмеченный работами Джона Голдторпа и коллег с фокусом на социальную структуру и стратификацию (Goldthorpe et al. 1987), и, наконец, период после 2000-х гг., ознаменованный культурным поворотом в исследованиях социальных классов, значительное влияние на которые оказали работы Пьера Бурдье (Bourdieu 1987; Savage 2016) и феминистских теоретиков (Crenshaw 1991; Skeggs 2004). Несмотря на утверждения ряда социологов об утрате рабочими и представителями других социальных групп классовой идентичности (Pakulski, Waters 1996), согласно недавним исследованиям, она продолжает играть важную роль в субъективном восприятии индивидами общества и своего места в нем (Savage et al. 2015). Классовая идентичность также вносит значительный вклад в упорядочивание социальных практик людей, находящихся в схожих условиях (Bourdieu 1987), структурирующих их социальную, экономическую и культурную жизнь. В этом смысле детальное изучение социальных практик открывает возможность для реконструкции идентичностей, которые создаются посредством действий, интеракций и коммуникаций.

Как отмечает Джереми Моррис, практики «обживания» пространства (habitability) в общем виде становятся одной из ключевых категорий, с помощью которых люди в моногородах придают смысл своей жизни в постсо- 
циалистическом пространстве (Morris 2015:43; 2016). Поэтому способом изучения повседневных практик и социальных идентичностей рабочих служат подходы социальной этнографии (Gobo, Molle 2017; Pilkington 2010:211; Wacquant 2002) и этнографического кейс-стади (Романов 2005) как стратегий исследования, направленных на последовательное и детальное изучение одного объекта с учетом различных доступных способов сбора данных, в том числе метода включенного наблюдения непосредственно на изучаемой территории. Отметим, что в рамках социальной этнографии рабочие районы рассматриваются как кейсы, т.е. целостные феномены, помещенные в определенный социальный контекст. Как отмечают Роберт МакДонал и коллеги, социальная этнография позволяет показать социологическую значимость связи между классом и местом при изучении живого опыта и повседневной жизни резидентов рабочих районов (MacDonald et al. 2005: 885).

В Советском Союзе в 1920-1930-х гг. сложился определенный порядок строительства рабочих районов вокруг промышленных предприятий, который базировался на советской идеологии. Иногда вокруг крупных индустриальных комплексов образовывались целые города, получая статус «градообразующих предприятий» (Morris 2015: 28). В редких случаях вокруг большого завода по проектам советских архитекторов строился социалистический город (соцгород), где, как предполагалось, рабочий класс будет иметь все необходимое для «счастливой жизни» (Ilchenko 2016: 55). Советский период заводской жизни рабочими воспринимается как «прекрасное время» и описывается в категориях гордости, счастья, единства на работе и во время досуга (Polukhina et al. 2017: 13).

После распада Советского Союза в 1991 г. государственные фабрики и заводы претерпели ряд изменений: часть из них была приватизирована и поделена на более мелкие производства (Morrison 2008). Рабочие районы, ранее поддерживаемые предприятиями, стали приходить в упадок и утратили свою привлекательность. Наряду с этим, в 1990-е гг. в Россию пришли зарубежные предприятия, которые функционируют сегодня в соответствии с новой экономической логикой и формируют новые паттерны и идентичности рабочих (Vanke 2018). В этом смысле изучение идентичности рабочих завода советской эпохи, функционирующего сегодня, на фоне перехода от советского общества к постсоветскому, представляет актуальность. Мы покажем, чем является идентичность современного рабочего в постсоветском пространстве, а также продемонстрируем некоторые эффекты социальной политики и ее значение для повседневной жизни изучаемого района.

\section{Этнографическое кейс-стади как жанр полевого исследования «на районе»}

Выбранный нами кейс- район Уралмаш-это жилой микрорайон северной части Екатеринбурга, одного из главных городов Урала, крупного рос- 
сийского региона. Он основан в 1927 г. как рабочий поселок одноименного «завода заводов», спроектированный советскими архитекторами как соцгород. Уральский завод тяжелого машиностроения (УЗТМ, Уралмашзавод) начал работать в 1933 г. и был крупнейшим заводом в СССР. В постсоветской России завод и район претерпели изменения ${ }^{1}$, но продолжают функционировать.

Настоящее полевое исследование выполнено в жанре этнографического кейс-стади (см.: Полухина 2017). Во время сбора данных, в мае-июне 2017 г., коллектив исследователей во главе с авторами статьи ${ }^{2}$ стали временными жителями района Уралмаш. Основной эмпирический материал составил 15 интервью с рабочими завода Уралмаш и жителями одноименного района. Интервью с рабочими, в среднем, длились 1,5 часа и проведены в разных контекстах: дома, на рабочем месте, во дворе, столовой-кафетерии. Интервью включали проективные методики- ментальные карты района Уралмаш и круги общения, визуализирующие социальный капитал и сети информанта. Некоторые интервью были совмещены с биографической прогулкой по району (Стрельникова, Ваньке 2017).

С целью получения данных о трансформации завода и района нами также проведены восемь экспертных интервью с администраторами завода, активистами, представителями арт-индустрий и главой района. Интервью с экспертами длились около 40 минут и освещали вопросы района и /или завода, в зависимости от профессионального профиля информанта. Все интервью проведены двумя и реже тремя исследователями. Регулярно велись дневники наблюдений, описывающие полевую работу: контексты интервью, практики и пространства района, личный опыт проживания «на районе». Метод анализа данных - тематический: мы анализировали материалы транскриптов и дневников наблюдений с точки зрения самовосприятия информантов и социальных практик изучаемой группы в постсоветский период.

\section{«Размывание» классовой идентичности рабочего Уралмаша после распада Советского Союза в 1990-е rr.}

Резкое изменение социальной политики и переход от плановой к рыночной экономике после 1991 г. привели к изменению принципов работы заводов, ухудшению положения рабочих, появлению новых экономических агентов. Как пишут исследователи, в этот период наблюдалось «резкое снижение объемов производства за счет сокращения государственного заказа, развала системы поставок, роста цен, кризиса неплатежей» (Борисов,

\footnotetext{
${ }^{1}$ На данный момент район Уралмаш включен в состав Орджоникидзевского района и считается микрорайоном.

2 Данные собраны Александриной Ваньке, Елизаветой Полухиной и Анной Стрельниковой.
} 
Козина 1994: 17-19). В целом можно говорить о снижении статуса рабочих, которые почувствовали ухудшение своего положения (там же:28).

Рабочие-информанты осторожно и немногословно рассказывают о периоде 1990-х гг. Но в биографических нарративах этот период является четкой границей: время резких перемен, «выживания», ощущения «покинутости», самовосприятия «жертвы». Однако, так как переходный период был травматичным и завершился относительно недавно, информанты с трудом артикулировали этот жизненный этап в интервью. Многие участники нашего проекта из-за резкого ухудшения условий труда (сокращения, многомесячные невыплаты заработной платы) покидали завод на время перемен, уходя в отрасли «новой экономики» такие как торговля и сервис. Однако «уралмашевский» круг общения в 2000-е гг. снова возвращал их в ряды рабочих завода: на освободившуюся на заводе вакансию приглашали бывшие коллеги, соседи по району.

По словам информантов, минувшие 1990-е гг. были тяжелейшим периодом в их жизни. Сейчас они не понимают, «как выжили»: из-за многомесячных задержек выплаты зарплаты семьи рабочих не могли реализовать базовые потребности в еде, испытывали голод. Работники завода, которые оставались работать, активно подрабатывали. Некоторые информанты во время отпуска ездили в другие регионы «в поля» собирать урожай, которого хватало на питание своего домохозяйства, затем его частично продавали среди знакомых. Садоводство и ведение личного подсобного хозяйства приобрело особое значение как способ пропитания. Занимались собирательством.

В период 1990-х гг. стремительно развивается особая группа жителей Уралмаша-спортсмены-любители, которые становятся неформальными контролерами зарождающейся новой экономики. В то время, как пишет Вадим Волков, «многие бандитские группировки культивировали здоровый образ жизни, запрещая, в отличие от воров, алкоголь и наркотики и поддерживая физическую форму в спортивных залах» (Волков 1999: 61). Рабочие, которые были менее благополучны, подрабатывали или официально работали в учреждениях, связанных с районной криминальной группировкой - точки питания, различные сервисы.

За время перемен самоощущение рабочих завода изменилось: если ранее, в советский период, они воспринимали себя как незаменимого «производителя государственной мощи», то в 1990-е гг. они становятся «ненужной» слабой группой, жертвой происходящих изменений. Рабочий район Уралмаш, где развиваются новые экономические практики и зарождается предпринимательская активность, становится площадкой для формирования группы бенефициаров появившегося режима: криминальной группировки, которая становится теневым контролером и отчасти работодателем района. Рабочий в новых реалиях пытается адаптироваться и найти «свое» место: кто-то «удерживается» на заводе и пытается подрабатывать, 
иные встраиваются в новую экономику района, часть покидает завод и район. Это время трансформаций показывает, как на территории Уралмаша постепенно завершается социалистический период «завода заводов», и начинается капиталистический этап «района со своими правилами».

\section{Множественная идентичность рабочих Уралмаша в постсоветский период 2000-2010-х rr.}

Идентичности заводских рабочих, которые формируются в период «стабилизации» в 2000-е гг., включают «советские» и «постсоветские» практики, схемы, смыслы и ценности. На завершающей стадии социальноэкономических трансформаций (рубеж 1990-2000-х гг.) и в контексте неолиберальных реформ 2010-х гг., которые привели к сокращению масштабов производства (Morrison 2008), рабочие Уралмашзавода утрачивают классовую идентичность, характерную для советского времени. В результате они воспроизводят или пере-присваивают иные идентификационные типы, но сохраняют память о советском прошлом и пытаются найти основания для идентичности вне сферы труда.

Утрата классовой и сохранение советской идентичностей в новых реалиях переживается уралмашевцами старшего поколения болезненно: «Про "Уралмаш"- это... все наше, это моя бабушка строила <... . Я считаю, что на Уралмаше все мое... Противно было смотреть, как оттуда вагонами все вывозится» (слесарь-сантехник, м., 53 г.). Тема эмоциональной утраты для рабочих советского поколения связана в первую очередь с массовыми сокращениями и разрушением Уралмашзавода, на котором некоторые информанты проработали почти всю жизнь. Несмотря на сворачивание производства (на фоне дискурсивно озвучиваемого курса на «ре-индустриализацию» в России), советская идентичность, выражающаяся в культуре «советского человека» и ностальгии по «советскому прошлому» (Стрельникова 2018), продолжает составлять основу мировосприятия заводских рабочих старшего возраста, которые с трудом адаптируются к новым экономическим реалиям. В этом смысле сегодня советская идентичность рабочих, ассоциирующаяся с такими ценностями, как «порядочность», «добросовестность», «трудолюбие», продолжает существовать в постсоветском контексте:

Если без лишней скромности, то я-хороший человек... Я был рад, что родился в Советском Союзе... Полностью соответствовал советским наработкам, которые вбивали в голову <...> Нормальные мужики, на них Россия и держится. [Вопрос: Что общего у этих людей?] Честь и достоинство человеческое... Прошлым живем. [Я] обычный человек (слесарь-сантехник, м., 53 г.).

Многие самоопределения информантов старшего возраста передают свойства носителя советской идентичности. Зачастую люди описывают 
себя как «хорошего человека», «обычного человека», «нормального человека», но в то же время отказываются воспринимать себя с точки зрения классовой принадлежности. Основные черты «советского человека» сводятся не к классовым характеристикам, а связаны, как правило, с личностными свойствами и такими категориями, как «честность», «достоинство», «доверчивость», «простота», «трудолюбие». Так, идентичность «советского человека», в том числе, выражающаяся в таких культурных практиках, как, например, посещение концертов в районных домах культуры, кружков художественной самодеятельности, выставок народного творчества, заменяет собой классовую идентичность.

В гендерном аспекте информант описывает себя как «нормального мужика», основу маскулинной идентичности которого составляет физический труд, практические навыки и способности делать что-либо своими руками, например, чинить автомобили или мебель (см.: Morris 2018). Фемининная идентичность заводской рабочей строится вокруг умений поддерживать порядок в доме, готовить еду и мастерить предметы домашнего обихода, например, вязать вещи, плести вазы из газет, делать украшения, шить платья. Согласно данным экспертных интервью, в советское время в районе существовали специальные кружки рукоделия и приготовления еды, в которые записывались женщины-заводчанки с целью научиться вкусно готовить, правильно сервировать стол и украшать жилье. Мы приводим примеры мужских и женских практик заводских рабочих на основе наблюдений, сделанных во время домашних интервью, когда информанты показывали, как они украшают свое жилье. Также мы опираемся на данные биографических прогулок, в ходе которых информанты демонстрировали места, где проводят свободное время.

Нарративы заводских рабочих старше 50-ти лет на предмет социальной самоидентификации показывают, что многие являются носителями идентичности «пенсионер», причем - «рабочих пенсионеров», которые имеют относительно невысокий, но стабильный доход за счет пенсии. Некоторые из наших информантов стремятся скорее выйти на пенсию не для того, чтобы отдыхать, а получать дополнительные социальные выплаты. Повышение пенсионного возраста приведет к обнищанию и ухудшению социального положения заводских рабочих, особенно проживающих на депривированных индустриальных территориях, поскольку, как показывает наше исследование, пенсия служит пусть небольшим и важным источником дохода «рабочих пенсионеров», но не отвечает их нуждам полностью. Важно, чтобы занятость была официальной: «На заводе работаешь потому что по трудовой... Как пенсию-то зарабатьвать? А фирмыл, где я раньше работала [без трудовой], их давно уже нет» (Аппаратчик насосных установок, ж., 49 л.).

Большинство участников исследования откладывают пенсию, рассматривая ее как источник дополнительных доходов. На сбережения 
некоторые информанты могут позволить себе поездки за границу примерно раз в год (данные приводятся на 2017 г.). Наряду с желанием быть работающим пенсионером, есть те, кто после наступления пенсии планируют отдыхать. Типичным местом «отдыха» рабочих служит сад (т.е. загородный садовый участок с маленьким домиком или без дома), в котором информанты проводят свои выходные и отпуск. Распространены домашние формы времяпровождения (Каравай 2016: 229).

\section{Классовая идентичность}

В чем заключаются особенности классовой идентичности современных заводских рабочих? Данные нашего исследования показывают, что заводчане старшего поколения не описывают себя в классовых категориях, что не означает, что классовые различия не играют роли в российском обществе. Вопрос о социальной принадлежности сначала ставил наших информантов в затруднительное положение, поскольку идентичности «пенсионеров», «россиян», «советских людей» оттесняли их восприятие себя как представителей социального класса на второй план. Поэтому для реконструкции классовой идентичности следует «локализовать» информантов в пространстве социальных различий (Bourdieu 1985: 724-725) и проанализировать их отношение к представителям других социальных групп, которое актуализируется в интеракциях и коммуникациях (Bottero, Irwin 2003: 467). В силу того, что «класс- основательно связан с неравенством» (Savage et al. 2015:45), классовая идентичность артикулируется в разговорах заводчан о «расслоении» и «неравенстве». В этом смысле классовая идентичность выражается через проговаривание социальных чувств информантов по отношению к таким как они т.е. рабочим, и социально иным - представителям других социальных групп, с которыми они сталкиваются в повседневной жизни:

Ну, вот, такой круг у нас, все рабоче-крестьянские. В этой вот кухне мы все и вертимся. Кто-то у нас, если повыше прыгнул- значит, уже выбыл из нас... сейчас есть конкретная граница, мол, ты такой, а ты такой. «Золотая молодежь» или кто-то еще... Контора у нас- это «элита»... Контора - это вышестоящее наше руководство [завода]. Даже наша секретарь- тоже «пуп земли». Как говорят, благородного пастуха дочь [смеется]. Никак к ней не обратишься по-простому (аппаратчик химводоочистки, ж., 54 г.).

В рассказах информантов присутствуют такие социальные категории, как «золотая молодежь», «элита», иногда «полицейские» («менты»), «бандиты», которым противопоставляются «обычные люди». В этом смысле, все, что связано с «рабочими» описывается с помощью прилагательных «простой», «попроще», «простецкий», «простые рабочие», «простые работяги», а то, что связано с «элитой», описывается как «высокомерное», 
«напыщенное». Так, социальные различия, скорее, артикулируются в нарративах заводских рабочих через сравнения себя с другими жителями района, с теми, с кем они пересекаются в повседневной жизни (Bottero 2019). Мы не располагаем достаточным количеством данных для сравнения идентичностей рабочих советского и постсоветского поколений. Однако отметим, опираясь на результаты других исследований, что в основе идентичности молодых рабочих лежит ориентация на рынок труда, индивидуализм при построении карьеры и стремление улучшить качество жизни за счет расширения потребительских возможностей (Walker 2011: 90, 99, 109; Тартаковская, Ваньке 2016:39).

Заводчане становятся «невидимой» социальной группой, лишенной голоса. Классическая идентичность рабочего символически обесценивается, поскольку, как мы отмечаем, на территорию индустриального района приходят девелоперы, представители современной культуры и искусства, городские активисты, которые навязывают рабочим новую идентичность, выражающуюся в современных практиках культурного потребления (Ваньке, Полухина 2018).

\section{Заключение}

Если в ранний советский период социальная политика была направлена на формирование устойчивой классовой идентичности рабочих, в том числе за счет идеологического проектирования промышленных комплексов и прилегающих к ним индустриальных районов, где рабочие могли бы жить «счастливой жизнью», то период 1990-х гг. ознаменовался резким спадом производства и, как следствие, ухудшением социального положения рабочих, утратой привычных жизненных ориентиров, самоощущением «жертвы обстоятельств» и «размыванием» классовой идентичности.

Кейс Уралмаша показывает, что на современном этапе в идентичности заводских рабочих совмещаются как «советские», так и «постсоветские» практики, смыслы и ценности. Советское прошлое остается важным ресурсом для поддержания идентичности заводских рабочих Уралмаша старших возрастов. Гендерная идентичность заводчан формируется вокруг навыков и умений делать что-либо своими руками. Маскулинная идентичность поддерживается за счет таких ценностей, сформированных советской системой, как «порядочность», «трудолюбие», «добросовестность», и таких повседневных практик, как проведение досуга в мужской компании в гараже, починка автомобилей и домашней мебели (Morris 2018). Фемининная идентичность воспроизводится посредством специфических культурных практик, например, посещение мероприятий в районных домах культуры и бытовых практик, например, обустройство дома, создание своими руками предметов быта и украшений. В пространстве индустриального района заводчане старшего поколения больше не идентифицируют себя с классом 
и становятся все более «незаметной» социальной группой, так как в условиях ограниченных ресурсов они не имеют доступа к публичной сфере и не могут принять стили жизни, продвигаемые новыми акторами.

\section{Выражение благодарности}

Статья подготовлена при финансовой поддержке РФФИ, грант № 17-3301006-ОГН «Прошлое и настоящее рабочих районов: трансформации социокультурной и территориальной идентичности».

\section{Описание полевых данных}

Таблица 1

Экспертные интервью

\begin{tabular}{l|l}
\hline № & Основная должность, сфера занятости на текущий момент \\
\hline 1 & Директор музея истории Екатеринбурга \\
2 & Социолог, житель района Уралмаш \\
3 & Редактор газеты Уралмашзавода 'За тяжелое машиностроение' \\
4 & Историк, сотрудник музея истории Екатеринбурга \\
5 & Работник музея истории Уралмашзавода \\
6 & $\begin{array}{l}\text { Фотограф, автор проекта про династии Уралмашзавода, житель района } \\
7\end{array}$ \\
8 & $\begin{array}{l}\text { Уралмаш } \\
\text { Глава Орджоникидзевского района }\end{array}$ \\
\hline
\end{tabular}

Таблииа 2

Интервью с рабочими завода Уралмаш и жителями одноименного района

\begin{tabular}{|c|c|c|c|c|}
\hline № & $\stackrel{5}{\S}$ & 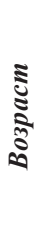 & 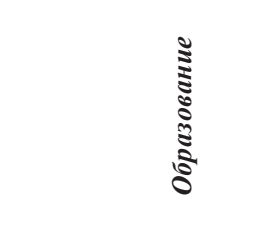 & 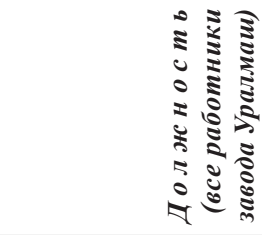 \\
\hline 1 & женский & 54 & среднее специальное & крановщица \\
\hline 2 & женский & 49 & среднее специальное & аппаратчик насосов \\
\hline 3 & мужской & 53 & среднее & слесарь-сантехник \\
\hline 4 & мужской & 57 & высшее & наладчик \\
\hline 5 & женский & 60 & среднее & слесарь \\
\hline
\end{tabular}




\begin{tabular}{|c|c|c|c|c|}
\hline 6 & женский & 43 & незаконченное высшее & нагревальщик-сварщик \\
\hline 7 & мужской & 42 & незаконченное высшее & $\begin{array}{l}\text { наладчик станков с ЧПУ } \\
\text { (числовое программное } \\
\text { управление) }\end{array}$ \\
\hline 8 & женский & 60 & среднее & $\begin{array}{l}\text { крановщица, машинист крана, } 6 \\
\text { разряд }\end{array}$ \\
\hline 9 & женский & 58 & среднее & аппаратчик химводоочистки \\
\hline 10 & мужской & 45 & среднее специальное & наметчик \\
\hline 11 & женский & 27 & $\begin{array}{l}\text { среднее, курсы повышения } \\
\text { квалификации на заводе }\end{array}$ & крановщица \\
\hline 12 & женский & 54 & среднее специальное & аппаратчик химводоочистки \\
\hline 13 & женский & 59 & $\begin{array}{l}\text { высшее, высшая партийная } \\
\text { школа, курсы повышения } \\
\text { квалификации на заводе }\end{array}$ & аппаратчик химводоочистки \\
\hline 14 & мужской & 29 & среднее специальное & $\begin{array}{l}\text { слесарь механосборочных работ } \\
\text { по обработке железных } \\
\text { агрегатов }\end{array}$ \\
\hline 15 & женский & 52 & среднее & машинист насосных установок \\
\hline
\end{tabular}

\section{Список источников}

Борисов В. А., Козина И. М. (1994) Об изменении статуса рабочих на предприятии. Социологические исследования, (11): 16-29.

Ваньке А. В., Полухина Е.В. (2018) Территориальная идентичность в индустриальных районах: культурные практики заводских рабочих и деятелей современного искусства. Laboratorium, 10 (3): 4-34.

Волков В.В. (1999) Силовое предпринимательство в современной России. Социологические исследования, (1):56-65.

Каравай А.В. (2016) Отношение российских рабочих к своим ресурсам: финансам, здоровью и свободному времени. Журнал исследований соичиальной политики, 14 (2): $229-244$.

Полухина Е.В. (2017) Уралмаш как район рабочего: методические аспекты применения этнографического кейс-стади. Л.Е. Петрова, М.С. Ильченко, А. А. Пронин, И. А. Ахьямова (ред.) Проект «Уралмаш»: культурное будущее [пост]индустриальных городов. Материалы международного симпозиума (Екатеринбург, 31 мая3 июня 2017 года). Т. 1. Екатеринбург: Екатеринбургская академия современного искусства: 25-37.

Романов П. В. (2005) Стратегия case-study в исследовании социальных служб. Сочиологические исследования, (4): 102-113. 
Стрельникова А. В., Ваньке А. В. (2017) Полевое исследование индустриального района: стратегии сбора и анализа визуальных данных. ИНТЕРакция. ИНТЕРвью. ИНТЕРпретация, (13): 51-72.

Стрельникова А.В. (2018) Смыслы жизни, укорененные в пространстве: ностальгическая идентичность жителей «заводских» районов. Ж. Тощенко (ред.) Смыслы жизни российской интеллигеничии. М.: РГГУ: 275-280.

Тартаковская И.Н., Ваньке А.В. (2016) Карьера рабочего как биографический выбор. Социологическое обозрение, 15 (3): 9-47.

Bottero W. (2019) A Sense of Inequality. London: Rowman and Littlefield.

Bottero W., Irwin S. (2003) Locating Difference: Class, 'Race' and Gender, and the Shaping of Social Inequalities. The Sociological Review, 51 (4):463-483.

Bourdieu P. (1987) Distinction. A Social Critique of the Judgement of Taste. Harvard: Harvard University Press.

Bourdieu P. (1985) Social Space and the Genesis of Groups. Theory and Society, 14 (6): 723-744.

Crenshaw K. (1991) Mapping the Margins: Intersectionality, Identity Politics, and Violence against Women of Color. Stanford Law Review, 43 (6): 1241-1299.

Gobo G., Molle A. (2017) Doing Ethnography. Thousand Oaks, CA: Sage.

Goldthorpe J., Llewellyn C., Payne C. (1987) Social Mobility and Class Structure in Modern Britain. Oxford: Clarendon Press.

Ilchenko M. (2016) 'Green' Utopia of the Uralmash: Institutional Effects and Symbolic Meaning. Critical Housing Analysis, 3 (2): 52-60.

MacDonald R., Shildrick T., Colin Webster C., Simpson D. (2005) Growing Up in Poor Neighbourhoods: The Significance of Class and Place in the Extended Transitions of 'Socially Excluded' Young Adults. Sociology, 39 (5): 873-891.

Morris J. (2015) Notes on the 'Worthless Dowry' of Soviet Industrial Modernity: Making Working-Class Russia Habitable. Laboratorium, 7 (3): 25-48.

Morris J. (2016) Everyday Post-Socialism. Working-Class Communities in Russian Margins. London: Palgrave MacMillan.

Morris J. (2018) Automobile Masculinities and Neoliberal Production Regimes among Russian Blue-Collar Men. In: C. Walker, S. Roberts (eds.) Masculinity, Labour, and Neoliberalism: Working-Class Men in International Perspective. London: Palgrave MacMillan: 171-193.

Morrison C. (2008) Russian Factory Enters the Market Economy. London: Routledge.

Pakulski J., Waters M. (1996) The Death of Social Class. London: Sage.

Pilkington H. (2010) Does It Have to End in Tears? Reflexivity and Team-Based Ethnography. In: H. Pilkington, E. Omelchenko, A. Garifzianova (eds.) Russia's Skinheads. Exploring and Rethinking Cultural Lives. London: Routledge: 211-223. 
Polukhina E., Strelnikova A., Vanke A. (2017) The Transformation of Working-Class Identity in Post-Soviet Russia: A Case-Study of an Ural Industrial Neighborhood. NRU Higher School of Economics. Series SOC 'Sociology', No. WP BRP 77/SOC/2017.

Savage M. (2005) Working-Class Identities in the 1960s: Revisiting the Affluent Worker Study. Sociology, 39 (5):929-946.

Savage M. (2016) The Fall and Rise of Class Analysis in British Sociology, 1950-2016. Tempo Social, 28 (2): 57-72.

Savage M., Cunningham N., Devine F., Friedman S., Laurison D., McKenzie L., Miles A., Snee A., Wakeling P. (2015) Social Class in the $21^{\text {st }}$ Century. London: Pelican.

Skeggs B. (2004) Class, Self, Culture. London: Routledge.

Vanke A. (2018) Masculinities, Bodies and Subjectivities: Working-Class Men Negotiating Russia's Post-Soviet Gender Order. In: C. Walker, S. Roberts (eds.) Masculinity, Labour, and Neoliberalism: Working-Class Men in International Perspective. London: Palgrave MacMillan: 195-218.

Wacquant L. (2002) Scrutinizing the Street: Poverty, Morality, and the Pitfalls of Urban Ethnography. American Journal of Sociology, 107 (6): 1468-1532.

Walker C. (2011) Learning to Labour in Post-Soviet Russia. Vocational Youth in Transition. London: Routledge. 


\title{
THE IDENTITY OF THE INDUSTRIAL WORKER IN A POST-SOVIET CONTEXT: AN ETHNOGRAPHIC CASE STUDY OF THE URALMASH DISTRICT
}

\begin{abstract}
This article is an examination of working-class identity based on various theories of cultural class analysis and genetic structuralism. Workers at the Uralmash factory, the largest of the Soviet enterprises still functioning in Russia today, were selected as the focus of empirical research. Ethnographic fieldwork was conducted from May to June 2017, when the researchers became temporary residents of the Uralmash district. The example of the Uralmash case shows that contemporary workers in the post-Soviet space bear multiple and fragmented identities that combine Soviet and post-Soviet practices and values. Workers describe themselves as 'ordinary' and 'good' people, reflecting personal traits and values such as honesty, industriousness, sociability, dignity, simplicity, as well as in terms of identity in private life, e.g. a family person, a pensioner, a gardener. Many representatives of elder generations perceive themselves as people 'living in the past', 'Soviet people'. Thus, the Soviet past remains the main resource and a 'universal' prop supporting subjective perception of factory workers of elder generations. 'District-level' patriotism is another significant sense-making resource for the identity of Uralmash workers. However, as our interviews and observation show, workers in the post-Soviet period have become an 'invisible' group in the district due to their tendency to reject new lifestyles offered by new actors such as developers, cultural activists, and representatives of the entertainment industry. Consequently, a factory worker in the post-Soviet period suffers the loss of the class identity typical for the Soviet period. As a result, workers reproduce or re-appropriate other identity types while retaining memories about the Soviet past and trying to find a new foundation for identity in private life.
\end{abstract}

Keywords: industrial district, factory worker, working-class identity, ethnographic case study, Uralmash

DOI: $10.17323 / 727-0634-2019-17-2-237-252$

\section{References}

Borisov V.A., Kozina I. M. (1994) Ob izmenenii statusa rabochikh na predpriyatii [Changing the Workers' Status at the Enterprise]. Sociological Studies, (11): 16-29.

Elizaveta Polukhina- PhD (kandidat nauk) in Sociology, Associate Professor in Sociology, National Research University Higher School of Economics (HSE), Moscow, Russian Federation. Email: epolukhina@hse.ru

Alexandrina Vanke- PhD (kandidat nauk) in Sociology, Doctoral researcher at the Department of Sociology of the University of Manchester, Manchester, UK. Research fellow at the State Academic University for the Humanities, Research fellow at the Federal Center of Theoretical and Applied Sociology of the Russian Academy of Sciences, Moscow, Russian Federation. Email: a.vanke@postrgad.macnhester.ac.uk 
Bottero W. (2019) A Sense of Inequality. London: Rowman and Littlefield.

Bottero W., Irwin S. (2003) Locating Difference: Class, 'Race' and Gender, and the Shaping of Social Inequalities. The Sociological Review, 51 (4): 463-483.

Bourdieu P. (1980) The Logic of Practice. Stanford: Stanford University Press.

Bourdieu P. (1987) Distinction. A Social Critique of the Judgement of Taste. Harvard: Harvard University Press.

Bourdieu P. (1985) Social Space and the Genesis of Groups. Theory and Society, 14 (6): 723-744.

Crenshaw K (1991) Mapping the Margins: Intersectionality, Identity Politics, and Violence against Women of Color. Stanford Law Review. 43 (6): 1241-1299.

Gobo G., Molle A. (2017) Doing Ethnography. Thousand Oaks, California: SAGE Publications Ltd.

Goldthorpe J., Llewellyn C., Payne C. (1987) Social Mobility and Class Structure in Modern Britain. Oxford: Clarendon Press.

Ilchenko M. (2016) 'Green' Utopia of the Uralmash: Institutional Effects and Symbolic Meaning. Critical Housing Analysis, 3 (2): 52-60.

Karavay A. V. (2016) The Attitude of Russian Workers to Managing their Resources: Finances, Health and Spare Time. The Journal of Social Policy Studies, 14 (2): 229-244.

MacDonald R., Shildrick T., Colin Webster C., Simpson D. (2005) Growing Up in Poor Neighbourhoods: The Significance of Class and Place in the Extended Transitions of 'Socially Excluded' Young Adults. Sociology, 39 (5): 873-891.

Morris J. (2015) Notes on the 'Worthless Dowry' of Soviet Industrial Modernity: Making Working-Class Russia Habitable. Laboratorium, 7 (3): 25-48.

Morris J. (2016) Everyday Post-Socialism. Working-Class Communities in Russian Margins. London: Palgrave MacMillan.

Morris J. (2018) Automobile Masculinities and Neoliberal Production Regimes Among Russian Blue-Collar Men. In: C. Walker, S. Roberts (eds.) Masculinity, Labour, and Neoliberalism: Working-Class Men in International Perspective. London: Palgrave MacMillan: 171-193.

Morrison C. (2008). A Russian Factory Enters the Market Economy. London: Routledge.

Pakulski J., Waters M. (1996) The Death of Social Class. London: Sage.

Pilkington H. (2010) Does It Have to End in Tears? Reflexivity and Team-Based Ethnography. In: H. Pilkington, E. Omelchenko, A. Garifzianova (eds.) Russia's Skinheads. Exploring and Rethinking Cultural Lives. London: Routledge: 211-223.

Polukhina E. V. (2017) Uralmashkak rayon rabochego: metodicheskie aspekty primeneniya etnograficheskogo keys-stadi [Uralmash as Neighborhood of Industrial Worker: the Specifics of the Ethnographic Case-Study Implementation]. In: L. E. Petrova, M. S. Il'chenko, A. A. Pronin, I. A. Akh'yamova (eds.) Project 'Uralmash': Cultural future of [post] industrial cities. Proceedings from the International Symposium. (Ekaterinburg, 31 may-3 june 2017). Ekaterinburg. Ekaterinburg Academy of Contemporary Art:25-37. 
Polukhina E., Strelnikova A., Vanke A. (2017) The Transformation of Working-Class Identity in Post-Soviet Russia: A Case-Study of an Ural Industrial Neighborhood / NRU Higher School of Economics. Series SOC 'Sociology'. No. WP BRP 77/SOC/2017.

Romanov P. V. (2005) Strategiya case-study v issledovanii sotsial'nykh sluzhb [Case-Study Research in Public Services]. Sociological Studies, (4): 102-113.

Savage M. (2005) Working-Class Identities in the 1960s: Revisiting the Affluent Worker Study. Sociology, 39 (5): 929-946.

Savage M. (2016) The Fall and Rise of Class Analysis in British Sociology, 1950-2016. Tempo Social, 28 (2): 57-72.

Savage M., Cunningham N., Devine F., Friedman S., Laurison D., McKenzie L., Miles A., Snee A., Wakeling P. (2015) Social Class in the 21 $1^{\text {st }}$ Century. London: Pelican.

Skeggs B. (2004) Class, Self, Culture. London: Routledge.

Skeggs B. (2005) The Making of Class and Gender through Visualizing Moral Subject Formation. Sociology, 39 (5): 965-982.

Strelnikova A. V., Vanke A. V. (2017) Polevoe issledovanie industrial'nogo rayona: strategii sbora i analiza vizual'nykh dannykh [Field Research of an Industrial Neighbourhood: The Strategies of Visual Data Collection and Analysis]. INTER: INTERaction. INTERview. INTERpretation, (13): 51-72.

Strelnikova A. V. (2018) Smysly zhizni, ukorenennye v prostranstve: nostal'gicheskaya identichnost' zhitelej 'zavodskih' rajonov [The Meaning of Life, Entrenchment and Space: Nostaligic Identity Among Inhabitants of Factory Districts]. In: Zh. Toshchenko (ed.) Smysly zhizni rossijskoj intelligencii [The Meaning of life in the Russian Intelligentsia]. Moscow: RSHU:275-280.

Tartakovskaia I.N., Vanke A. (2016) Kar'era rabochego kak biograficheskij vybor [The Working-Class Career as Biographical Choice]. Russian Sociological Review. 13 (3):9-47.

Vanke A. (2018) Masculinities, Bodies and Subjectivities: Working-Class Men Negotiating Russia's Post-Soviet Gender Order. In: C. Walker, S. Roberts (eds.) Masculinity, Labour, and Neoliberalism: Working-Class Men in International Perspective. London: Palgrave MacMillan: 195-218.

Volkov V.V. (1999) Silovoe predprinimatel'stvo v sovremennoy Rossii [Forceful Entrepreneurship in Modern Russia]. Sociological Studies, (1): 56-65.

Wacquant L. (2002) Scrutinizing the Street: Poverty, Morality, and the Pitfalls of Urban Ethnography. American Journal of Sociology.107 (6): 1468-1532.

Walker C. (2011) Learning to Labour in Post-Soviet Russia. Vocational Youth in Transition. London: Routledge. 